\title{
Penerapan Battery Test sebagai Rekomendasi Jurusan di Perguruan Tinggi
}

\author{
Application of Battery Test as a Recommendation Departments in College
}

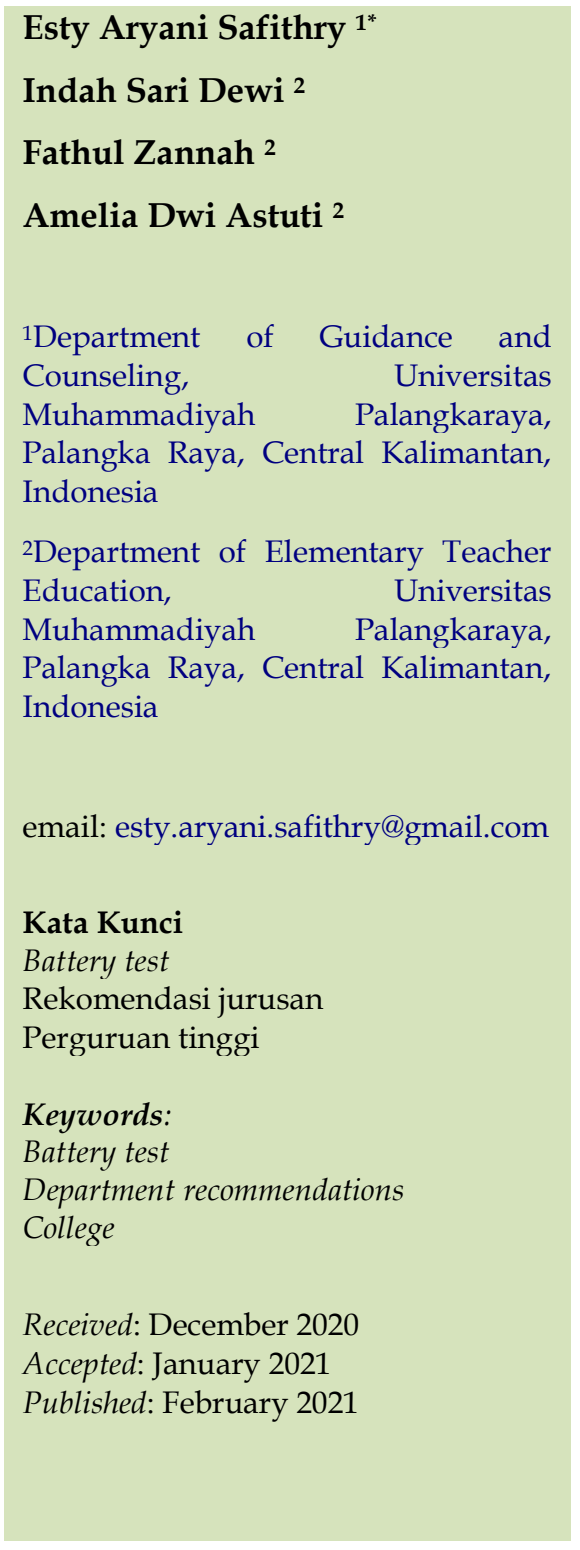

\begin{abstract}
Abstrak
Potensi siswa dapat diketahui dengan cara melaksanakan tes psikologis yang mendeskipsikan gambaran pribadi siswa. Ada 3 komponen tes yang diberikan yaitu tes integensi (IST), minat pekerjaan (Tes Kuder) dan tes kepribadian (EPPS). Gabungan tiga tes ini dinamakan battery test yang hasil laporan psikologisnya berisi psikogram mengenai aspek-aspek pribadi, deskripsi psikologis, kelebihan dan kekurangan diri serta rekomendasi bidang pekerjaan yang sesuai.Kegiatan ini direncanakan di laksanakan di lembaga luar sekolah seperti tempat kursus atau lembaga bimbingan belajar. Berdasarkan evaluasi mengenai penilaian terhadap diri menunjukan peserta sudah mampu memahami kondisi diri pribadi berikut kelebihan dan kelemahannya, area pribadi yang perlu dikembangkan dan rekomendasi jurusan perguruan tinggi yang sesuai dengan bakat, minat pribadi peserta, evaluasi mengenai penilaian terhadap kegiatan pelatihan menunjukan hasil bahwa pelatihan ini memberikan manfaat kepada peserta khususnya mengenai rekomendasi perguran tinggi dan penilaian terhadap pemateri dimana pemateri dinilai sudah cukup baik dalam penyampaian materi kegiatan.
\end{abstract}

\begin{abstract}
The potential of students can be identified by carrying out psychological tests that describe students' personalities. There are 3 components of the test given, namely the integration test (IST), job interest (Kuder test), and personality test (EPPS). The combination of these three tests is called a battery test which results in a psychological report containing a psychogram regarding personal aspects, psychological descriptions, strengths, and weaknesses as well as recommendations for the appropriate field of work. This activity is planned to be carried out in nonschool institutions such as courses or tutoring institutions. Based on the evaluation of self-assessment, it shows that participants are able to understand their personal condition along with their strengths and weaknesses, personal areas that need to be developed, and recommendations for higher education majors that are in accordance with their talents, personal interests of participants, evaluation of assessments of training activities shows the results that this training provides benefits to participants, especially regarding college recommendations and assessment of presenters where the presenters are considered good enough in delivering activity material.
\end{abstract}

(C) 2021 Esty Aryani Safithry, Indah Sari Dewi, Fathul Zannah, Amelia Dwi Astuti. Published by Institute for Research and Community Services Universitas Muhammadiyah Palangkaraya. This is Open Access article under the CC-BY-SA License (http://creativecommons.org/licenses/by-sa/4.0/). DOI: https://doi.org/10.33084/pengabdianmu.v6i2.1864

\section{PENDAHULUAN}

Pada dasarnya setiap siswa memiliki suatu keinginan atau minat untuk melanjutkan studinya ke jenjang yang lebih tinggi. Slameto (2003) mengatakan bahwa "Minat adalah kecenderungan yang tetap untuk memperhatikan dan mengenang kegiatan-kegiatan yang diminati seseorang, diperhatikan terus-menerus yang disertai dengan rasa senang". Siswa masuk ke perguruan tinggi dengan tujuan untuk meneruskan 
karir yang ia inginkan. Orang tua sangat berperan aktif dalam menumbuhkan minat siswa melanjutkan studinya kejenjang yang lebih tinggi.

Sebagian besar orang telah bersekolah mulai dari tingkat Taman Kanak-kanak (TK) sampai perguruan tinggi, namun ada sebagian lain yang menganggap pendidikan tinggi bukan hal yang penting, asalkan sudah bekerja dan menghasilkan uang maka tidak perlu pendidikan tinggi. Di provinsi Kalimantan Tengah, menurut hasil survey tahun 2018 dari Badan Pusat Statistik Kalimantan Tengah (2018) menunjukan angka rata-rata lama sekolah mencapai 8,37 tahun, menduduki urutan ke 19 dari 34 provinsi di Indonesia. Berdasarkan data diatas dapat ditarik kesimpulan bahwa rata-rata penduduk di Kalimantan Tengah bersekolah hanya sampai pada jenjang menengah pertama.

Hasil studi pendahuluan pada 10 sekolah menengah atas negeri dan swasta yang merupakan mitra dari UM Palangkaraya menunjukan minat siswa masuk ke perguruan tinggi dengan rincian $67 \%$ memiliki minat tinggi, 25\% dengan minat sedang dan $8 \%$ memiliki minat rendah untuk masuk ke perguruan tinggi. Namun ada beberapa kendala yang membuat siswa masih ragu untuk melanjutkan studi ke perguruan tinggi yaitu belum mengetahui secara pasti jurusan yang tepat untuk dirinya (45\%), ada yang sudah mempunyai bayangan akan masuk kejurusan apa namun terkendala dengan keinginan orang tua yang berbeda $(28 \%)$, sudah mengetahui akan masuk ke jurusan yang diinginkan namun masih merasa kurang percaya diri $(20 \%)$ dan hanya $7 \%$ yang sudah memutuskan akan masuk ke jurusan yang diinginkan. Siswa juga diberikan angket mengenai apa saja tantangan masuk perguruan tinggi, sebagian besar menjawab dalam memilih jurusan yang tepat $(40 \%)$, kurangnya kemampuan diri $(27 \%)$, biaya kuliah yang semakin tinggi (16\%), daya tamping perguruan tinggi yang terbatas $(10 \%)$ dan lokasi
Perguruan tinggi yang letaknya jauh dari tempat tinggal $(7 \%)$.

Di sekolah tempat penelitian dilaksanakan yaitu pada SMAN 1 dan SMAN 2 pada kelas $X$ sudah diterapkan penjurusan yaitu jurusan antara IPA, IPS dan Bahasa. Alasan mengapa diadakan penjurusan mulai dari kelas $\mathrm{X}$ adalah agar siswa mempunyai bayangan mengenai jurusan atau prodi apa yang akan ia tempuh jika ia melanjutkan studi ke perguruan tinggi. Harapanya dengan adanya penjurusan ini siswa dapat arahan yang jelas mengenai jurusan yang nantinya akan ditempuh. Penjurusan siswa di SMA merupakan titik awal bagi keberhasilan profesi siswa di masa depan, dijelaskan lebih lanjut bahwa siswa yang memilih jurusan berdasarkan pertimbangan bakat dan minat akan merasa senang mempelajari ilmu di jurusan yang telah dipilih, dan sebaliknya mempelajari sesuatu yang tidak sesuai dengan kemampuan, bakat dan minat sangat tidak menyenangkan (Devianti, 2015).

Namun berdasarkan wawancara dengan guru BK penjurusan yang dilakukan sejak kelas X tidak menjamin ia akan mengambil jurusan yang sama saat kuliah, misal jurusan IPA mengambil jurusan sosial seperti sospol atau pendidikan social dan lainya. Selain itu, keputusan untuk memilih jurusan terkadang tidak berdasarkan alasan yang realistis dan rasional, meraka cenderung ikut-ikutan dengan teman sebayanya dalam memilih jurusan. hal tersebut disebabkan adanya faktor kohesivitas kelompok teman sebaya. Hal ini dikuatkan dengan adanya pandangan di masyarakat bahwa ketika mengambil jurusan atau prodi tertentu akan dipandang lebih istimewa daripada jurusan yang lain, dikuatkan juga dengan orang tua yang mengharuskan siswa untuk mengambil jurusan yang favorit tanpa mempertimbangkan bakat dan minat siswa Terkadang pula para siswa tidak memahami alasan masuk jurusan 
tertentu, apa yang akan dilakukan setelah lulus SMA, dan apa yang menjadi cita-citanya.

Jika siswa memilih jurusan atau prodi yang kurang tepat dengan gambaran pribadi dirinya dapat menyebakan potensi siswa tersebut sulit untuk berkembang sehingga presasi yang diharapkan tidak muncul. Fenomena drop out di perguruan tinggi salah satu bentuk dari salahnya pemilihan jurusan yang ditempuh oleh mahasiswa (Kumala et al., 2016). Dengan begitu, diperlukannya kegiatan bimbingan karier disekolah, namun kendalanya adalah mayoritas sekolah tidak mempunyai jam pelajaran khusus untuk mata pelajaran BK atau hanya mempunyai 45 menit dalam satu minggu, dimana dengan banyaknya siswa tidak mencukupi untuk melaksanakan bimbingan karir di sekolah (Novianto et al., 2013).

Kegiatan pengabdian pada masyarakat ini berisi kegitankegiatan seperti pemaparan mengenai pentingnya pendidikan tinggi untuk kehidupan yang lebih baik,dan penjelasan mengenai berbagai peluang dan tantangan masing-masing bidang pekerjaan. Dalam menentukan jurusan atau program studi yang tepat diperlukan tes Psikologi yang tepat, mengingat setiap siswa memiliki kemampuan yang berbeda-beda, bakat minat yang beragam dan tipe-tipe keribadian serta gaya belajar yang berbeda pula (Azizah \& Naqiyah, 2017). Tes yang digunakan yaitu Intelegence Structure Test (IST) untuk mengetahui Kemampuan umum dan khusus siswa, Tes Kuder Preference Record - Vocational (KPR-V) untuk mengetahui minat pekerjaan, Tes Edward Personal Preference Schedule (EPPS), tes gaya belajar (VAK).

Kegiatan ini direncanakan di laksanakan di lembaga luar sekolah seperti tempat kursus atau lembaga bimbingan belajar. Alasan dilaksanakan kegiatan ini dilaksanakan pada lembaga bimbingan belajar adalah salah satu lembaga pendidikan non formal dimana fungsinya adalah untuk mengganti, menambah, dan melengkapi pendidikan formal. Bimbingan belajar mengacu kepada kurikulum yang berlaku, metode yang menyenangkan dan menggunakan trik belajar tertentu sehingga siswa tak jenuh dan mudah memahami materi yang disampaikan sesuai kebutuhan dan menunjang kebutuhan siswa disekolah (Efendi, 2018). Salah satu kebutuhan siswa selain memaksimalkan hasil belajar adalah menemukan potensi diri siswa agar dapat dapat menempuh pendidikan lanjutan sesuai dengan minat dan bakat yang ia miliki.

\section{METODOLOGI}

Kegiatan ini terbagi menjadi beberapa tahap yaitu:

1. Tahap Persiapan

Tahap persiapan ini kegiatanya adalah menyusun rancangan kegiatan, kegiatan ini berupa persiapan sebelum kegiatan seperti materi apa saja yang akan diberikan, waktu pelaksanaan yang sesuai dengan kesepakatan peserta, serta hal-hal lain yang terkait dengan penyelengaraan kegiatan. Kemudian adalah tahap perijinan dan koordinasi dengan instansi terkait dan tahap.

2. Pelaksanaan Kegiatan

Pelaksanaan ini yang terdiri dari kegiatan ceramah, penerapan battery test dan FGD. Kegiatan ceramah dengan materi mengenai pengenalan diri. Topik yang diberikan mengenai, aku dan diriku, kesadaran diri: siapakah aku? penghargaan diri, apa yang kumau? membangun kepercayaan diri, dinamika otak dan pikiran, membangun impian dan cita-cita, happiness, mewujudkan impian dan cita-cita, optimisme: yes, i can! Kemudian mengenai gambaran kehidupan di perguruan tinggi. topic pada kegiatan ini adalah mengenai, pentingnya melanjutkan studi ke perguruan tinggi, bagaimana cara menyesuaikan diri dengan kehidupan kampus, hambatan yang mungkin dihadapi dan solusinya. 


\section{Pelaksanaan tes IST}

Tes IST (Intelligenz Struktur Test) merupakan salah satu tes psikologi untuk mengukur tingkat intelegensi seseorang. IST terdiri dari sembilan subtes yang keseluruhannya berjumlah 176 item. Masingmasing subtes memiliki batas waktu yang berbedabeda dan diadministrasikan dengan menggunakan manual. Material tes terdiri dari buku soal dan lembar jawaban untuk siswa, kunci jawaban dan manual untuk tester.

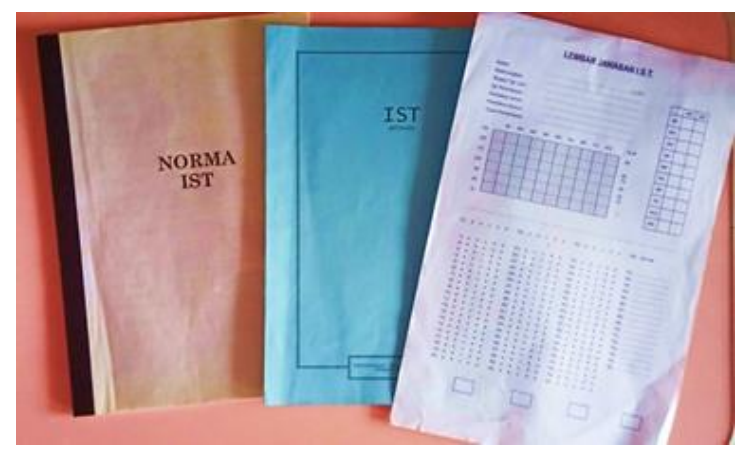

Gambar 1. Perangkat Tes IST

4. Tes Kuder Preference Record

Merupakan tes minat pekerjaan. terdiri atas 100 item pertanyaan yang menjelaskan beragam aktivitas dari yang paling disukai dan yang kurang disukai. Waktu mengerjakan tes ini sekitar 40-60 menit. Material Tes terdiri dari buku soal, Lembar Jawaban, Kunci Kuder Nomor 0, 1, 2, 3, 4, 5, 6, 7, 8, 9, dan Kunci V (11 kunci), Norma Standart Kuder dan Alat Tulis.

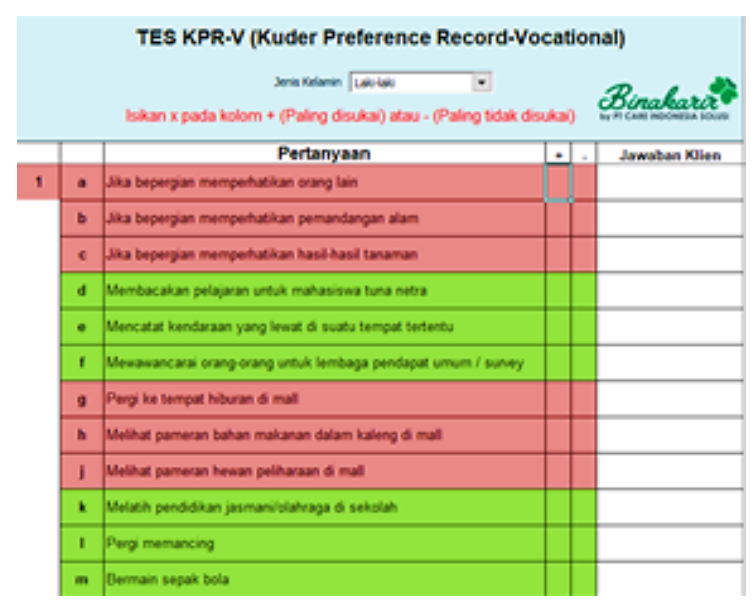

Gambar 2. Software tes Kuder
5. Tes Edward Personal Preference Schedule (EPPS)

Tes Edwards Personal Preference Schedule (EPPS) adalah tes kepribadian yang diturunkan dari teori H.A. Murray yang mengukur tingkat individu dalam 15 kebutuhan dan motivasi umum. Dalam tes EPPS ini tak ada jawaban yang benar dan jawaban yang salah. Namun hanya merupakan tes yang mengetahui tipetipe motivasi, kebutuhan dan kesukaan pribadi.

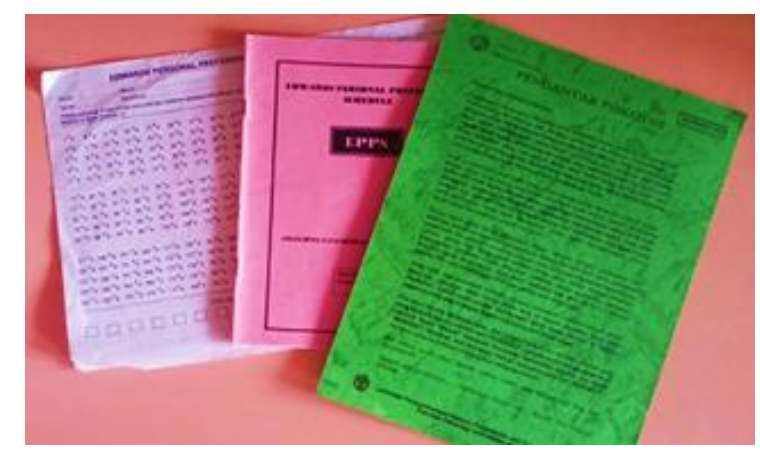

Gambar 3. Perangkat Tes EPPS

\section{Pelaksanaan FGD}

Focus Grup Discussion adalah melaksanakan diskusi pada sekelompok kecil yang dipimpin seorang narasumber atau moderator yang tugas mereka adalah mendorong peserta diskusi untuk berani berbicara terbuka dan spontan mengenai hal yang dipikirkanya yang dianggap penting namun berhubungan dengan topik diskusi yang sedang dibahas.

\section{Evaluasi Program}

Untuk mengetahui apakah kegiatan ini berjalan sesuai dengan tujuan maka diperlukan evaluasi. Pada setiap akhir sesi siswa diberikan lembar evaluasi yang terdiri dari 3 macam yaitu Lembar evaluasi penilaian terhadap diri sendiri, Lembar evaluasi terhadap kegiatan dan Lembar evaluasi terhadap pemateri.

\section{HASIL DAN PEMBAHASAN}

Hasil dari pelaksanaan pengabdian ini, akan dijabarkan dibawah ini sesuai dengan langkah-langkah atau 
metode pelaksanaan kegiatan pengabdian yang dilakukan.

1. Tahap Persiapan/Penyusunan rancangan Kegiatan Kegiatan ini berupa persiapan sebelum kegiatan seperti materi apa saja yang akan diberikan, waktu pelaksanaan yang sesuai dengan kesepakatan peserta, serta hal-hal lain yang terkait dengan penyelengaraan kegiatan. Tahap perijinan dan koordinasi dengan instansi terkait dalam hal ini adalah pihak sekolah sebagai penyedia tempat kegiatan.

a. Penyusunan surat menyurat mengenai kepanitiaan, pakar/narasumber dan fasilitator

b. Penyusunan surat-surat seperti surat kesediaan peserta, ijin tempat kegiatan, permohonan menjadi narasumber, undangan dll)

c. Pengandaan bahan ceramah dan diskusi.

d. Rapat persiapan akhir untuk memastikan peserta yang hadir, kesediaan tempat dan peralatan yang dibutuhkan.

2. Tahap Pelaksanaan Kegiatan

a. Kegiatan ceramah

Kegiatan ini merupakan sesi pertama dari seluruh kegiatan. Pemateri kegiatan ini adalah ibu Dr. Indah Sari Dewi M.Pd. dan Ibu Dr. Fathul Zannah, M.Pd. Ada 2 macam meteri yang diberikan pada kegiatan ceramah ini yaitu pengenalan diri. Topik yang diberikan mengenai, aku dan diriku, kesadaran diri: siapakah aku? penghargaan diri, apa yang kumau? membangun kepercayaan diri, dinamika otak dan pikiran, membangun impian dan cita-cita, happiness, mewujudkan impian dan cita-cita, optimisme: yes, i can! Kemudian tema mengenai gambaran kehidupan di perguruan tinggi. topik pada kegiatan ini adalah mengenai, pentingnya melanjutkan studi ke perguruan tinggi, bagaimana cara menyesuaikan diri dengan kehidupan kampus, hambatan yang mungkin dihadapi dan solusinya.

b. Pelaksanaan Battery test

Pada kegiatan ini hasil dari tiga tes diatas dianalisis sesuai dengan manual tes. Sebelum tes dikoreksi tester membuat psikogram yang berisi aspek-aspek pada setiap psikotes yang kemudian diisi sesuai dengan hasilnya. Untuk Tes IST dikoreksi terlebih dahulu untuk menemukan skor kasarnya kemudian dikonversikan ke dalam table IQ untuk mendapatkan nilai dari IQ tersebut. Untuk tes Kuder diperiksa sesuai dengan buku manual kemudian ditemukan bidang minat pekerjaan yang cocok. Tes EPPS dikoreksi yang kemudian menghasilkan gambaran kepribadian. Semua hasil tes tersebut di padukan menjadi laporan psikologis yang berisikan gambaran kemampuan umum, arah bakat dan minat pekerjaan serta gamabran kepribadian, serta kelebihan diri dan area pengembangan kemudian pada bagian akhir laporan psikologis berisi tiga rekomendasi jurusan yang sesuai dengan gambaran pribadi. Hasil ini didiskusikan pada proses FGD untuk membantu siswa mengambil keputusan mengenai jurusan yang akan diambil.

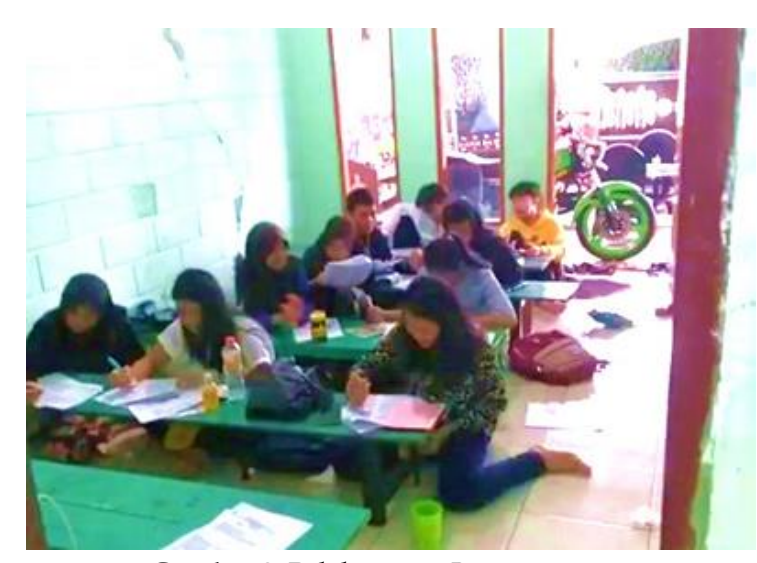

Gambar 3. Pelaksanaan Battery test 


\section{Evaluasi Program}

Untuk mengetahui apakah kegiatan ini berjalan sesuai dengan tujuan maka diperlukan evaluasi. Pada setiap akhir sesi siswa diberikan lembar evaluasi yang terdiri dari 3 macam yaitu

a. Lembar evaluasi penilaian terhadap diri sendiri. Lembar evaluasi bertujuan untuk mengetahui apakah ada perubahan diri setelah melakukan kegiatan. Lembar ini terdiri penilaian mulai dari angka 1 yang berarti sangat kurang sampai 5 yang berarti sangat besar. Itemnya terdiri dari 12 peryataan mengenai manfaat yang dirasakan. Hasil dari evaluasi penilaian diri sendiri ini menunjukan sebagian besar dari peserta (23 orang) mengetahui dapat gambaran diri mereka berikut kelebihan dan kekurangan diri serta rekomendasi pilihan jurusan perguruan tinggi yang cocok dnegan pribadi mereka.

b. Lembar evaluasi terhadap kegiatan. Lembar evaluasi ini bertujuan untuk mengetahui seberapa besar kegaitan ini memberikan manfaat pada siswa. penilaian mulai dari angka 1 yang berarti sangat kurang sampai 5 yang berarti sangat besar. Hasil dari evaluasi ini menunjukan semua peserta (25 0rang) menyatakan bahwa mereka merasakan banyak manfaat dan puas terhadap kegiatan ini.

c. Lembar evaluasi terhadap pemateri. Lembar evaluasi ini bertujuan untuk mengetahui bagaimana sikap pemateri selama kegiatan. Terdiri dari aspek-aspek perilaku yang terdiri dari aspek penerimaa, empati, motivator, pengusaan metode, kejelasan amteri, pengarahan dan kesungguhan, apakah sangat kurang, kurang, cukup, baik dan sangat baik. Hasil dari evaluasi ini menunjukan semua peserta menyatakan bahwa pemateri cukup bagus dalam penyampaian, baik saat kegiatan ceramah, pemberian instruksi tes dan proses FGD. Materi yang diberikan juga sangat jelas dan mudah dimengerti.

Pelaksanaan tes psikologi dengan menggunakan Battery test diketahui secara jelas gambaran psikologis siswa, battery test yang berisi kemampuan umum, arah bakat dan minat, deskripsi kepribadian dan gaya belajar serta rekomendasi jurusan yang sesuai dengan gambaran psikologis dirinya. Battery test yang diberikan dapat menggambarkan secara jelas bagaimana potensi diri siswa yang dihubungkan dengan jurusan yang dituju. Tes psikologi adalah alat ukur yang obyektif dan dibakukan atas sampelperilaku tertentu yang berfungsi untuk mengukur perbedaan-perbedaan antaraindividuindividu atau antara reaksi-reaksi individu yang sama dalam situasi yangberbeda (Anastasi \& Urbina, 1997).

Tes psikologi memiliki beberapa fungsi-fungsi tertentu. Tes dapat memberikan data untuk membantu para siswa dalm meningkatkan pemahaman diri (self understanding), dan penilaian diri (self evaluation), dan penerimaan diri (selfacceptance). Hasil tes psikologi dapat digunakan siswa untuk meningkatkan persepsi dirinya secara optimal dan mengembangkan eksplorasi dalam beberapa bidang tertentu. Di samping itu tes psikologi berfungsi dalam memprediksi, memperkuat, dan meyakinkan para siswa. Dalam menyajikan fungsifungsi hasil tes psikologis, tes psikologis dapat digunakan sebagai suatu alat prediksi, suatu bantuan diagnosis, suatu alat pemantau (monitoring), dan sebagai suatu instrument evaluasi (Sukardi \& Kusmawati, 2009).

Bagi peserta didik dan juga pihak sekolah, hasil tes psikologi dapat membantu dalam memprediksi keberhasilan atau ke tingkat keberhasilan tertentu, yaitu memungkinkan seorang peserta didik memiliki harapan dalam bidang studi tertentu, penjurusan dalam 
peminatan. Kemudian seorang psikolog sekolah atau konselor sekolah akan menyampaikan hasil tes psikologi ini kepada peserta didik dan menjelaskan kepadanya fungsi dan peranan dari tes yang telah dijalaninya dan dapat mengambil keputusan yang bermakna dan layak serta sesuai dengan ketentuan-ketentuan yang telah ditetapkan (Sukardi \& Kusmawati, 2009).

Tes psikologi juga digunakan dalam konseling pendidikan dan pekerjaan pada tingkat sekolah menengah dan universitas. Tidak jarang kita menjumpai siswa yang pandai saat sekolah menengah atas kemudian diterima di perguruan tinggi ternama namun kemudian justru mengalami kemunduran saat kuliah bahkan hingga keluar dan berpindah jurusan. Hal ini disebabkan yang menjadi pertimbangan saat pemilihan jurusan tidak hanya kemampuan akademis dan kesesuaian minat yang diperlukan tetapi juga prestise maupun pertimbangan kemudahan mendapat pekerjaan saat lulus nanti. Melalui tes psikologi, psikolog dapat menginterpretasikan hasil tes dan menyampaikan hasilnya pada pengguna tes dan orangtuanya sebagai dasar acuan dalam pemilihan jurusan maupun dalam pemilihan pekerjaan sehingga anak tidak akan merasa terjebak dalam pemilihan jurusan yang salah yang tidak sesuai dengan kemampuan serta bakat dan minat yang ia miliki (Daulay, 2014).

\section{KESIMPULAN}

Berdasarkan evaluasi mengenai penilaian terhadap diri menunjukan peserta sudah mampu memahami kondisi diri pribadi berikut kelebihan dan kelemahannya, area pribadi yang perlu dikembangkan dan rekomendasi jurusan perguruan tinggi yang sesuai dengan bakat, minat pribadi peserta, evaluasi mengenai penilaian terhadap kegiatan pelatihan menunjukan hasil bahwa pelatihan ini memberikan manfaat kepada peserta khususnya mengenai rekomendasi perguran tinggi dan penilaian terhadap pemateri dimana pemateri dinilai sudah cukup baik dalam penyampaian materi kegiatan.

\section{UCAPAN TERIMA KASIH}

Ucapan terima kasih serta penghargaan sebesarbesarnya tim pelaksana pengabdian yang berjudul "Penerapan battery test sebagai rekomendasi Jurusan di perguruan tinggi" kepada Lembaga penelitian dan pengabdian kepada Masyarakat yang telah mendanai kegaitan ini melalui Hibah Pengabdian Kepada Masyarakat dengan skema PKMS, Bimbingan Belajar, "Lely Studi Club" selaku tempat penyelanggaraan kegiatan dan terutama 25 siswa yang menjadi peserta selama kegiatan pelaksanaan berlangsung, serta seluruh tim pelaksana pengabdian yang telah banyak membantu untuk mensukseskan kegiatan pengabdian ini.

\section{REFERENSI}

Anastasi, A., Urbina, S. 1997. Psychological Testing. $7^{\text {th }}$ edition. New Jersey: Prentice-Hall, Inc.

Azizah, N., Naqiyah, N. 2017. Penggunaan Tangga Masa Depan Dalam Layanan Informasi Untuk Meningkatkan Perencanaan Karir Siswa Kelas X IPA Di SMA Negeri 11 Surabaya. Jurnal BK Unesa. 7(1):18.

Badan Pusat Statistik Kalimantan Tengah. 2018. Statistik Kalimantan Tengah Tahun 2018. Palangka Raya: Badan Pusat Statistik.

Daulay, N. 2014. Implementasi Tes Psikologi Dalam Bidang Pendidikan. Jurnal Tarbiyah. 21(2):402421. http://dx.doi.org/10.30829/tar.v21i2.13

Devianti, R. 2015. Kontribusi Dukungan Orangtua, Teman Sebaya, dan Guru Bimbingan dan Konseling terhadap MinatSiswa pada Jurusan yang Ditempati di SMA. Jurnal Konseling dan Pendidikan. 3(2):22-30. https://doi.org/10.29210/112600

Efendi, N.M. 2018. Revolusi Pembelajaran Berbasis Digital (Penggunaan Animasi Digital Pada Start Up Sebagai Metode Pembelajaran Siswa Belajar Aktif). Habitus: Jurnal Pendidikan, 
Sosiologi, dan Antropologi. 2(2):173-182. https://doi.org/10.20961/habitus.v2i2.28788

Kumala, A.T., Benarkah, N., Tjandra, E. 2016. Pembuatan Sistem Pendukung Keputusan Pemilihan Jurusan Kuliah Bagi Siswa Sma Berbasis Web Dengan Metode Promethee. Calyptra.4(2):1-10.

Novianto, Nursallim, M., Pratiwi, T.I, Setiawati, D. 2013. Studi Tentang Alokasi Jam Masuk Kelas Bagi BK dan Dampaknya di Sekolah Menengah Negeri se-Kec. Sumberrejo Bojonegoro. Jurnal BK UNESA. 3(1):81-89.

Slameto. 2003. Belajar dan Faktor-faktor yang Mempengaruhinya. Jakarta: Rineka Cipta.

Sukardi, D., Kusmawati, D. 2009. Analisis Tes Psikologis Teori \& Praktik. Jakarta: Rineka Cipta. 